\title{
1 Subsidizing Foreign Investments Through EU Funds in the European Peripheries: The Case of the Automotive Sector in East-Central Europe
}

\author{
Vera Šćepanović ${ }^{26}$, Gergő Medve-Bálint ${ }^{27}$
}

\begin{abstract}
After many years of being touted as success, the foreign direct investment (FDI)-oriented development model of East-Central Europe (ECE) has recently come under fire. The controversy is closely linked to discussions on the effects of EU integration for the development of poorer Eastern member states. Our paper contributes to these debates by investigating the neglected relationship between FDI and EU funds, where EU funds are used as investment incentives for FDI. The interaction between them is problematic, as these two types of external funds have fundamentally different purposes. Whereas FDI is driven by market logic, the EU funds are supposed to correct market inequalities and failures. However, we argue that, due to a combination of the ECE's structural dependence on foreign capital and design of funding allocation mechanisms, the EU funds may in fact amplify the existing market inequalities. To examine whether the EU funds to the private sector in ECE are market correcting or market amplifying, we analyse allocation of EU funds to the automotive industry in Poland and Romania in the 2007-13 programming period. We find some evidence for the market-correcting effects, in that foreign multinationals receive a smaller portion of these funds, relative to their share of employment and output of the sector, and that there is no bias towards foreign companies once we control for other firm characteristics. However, we also find that due to the peculiarities of the industry, where ownership, size, and productivity strongly overlap, a very large portion of EU funds - one half to three quarters-is nevertheless spent on subsidies to multinationals. Moreover, the overwhelming majority of these funds support routine capital investments instead of promoting innovative projects. We thus confirm the existence of a perverse mechanism in the distribution of EU funds in ECE, whereby the least developed regions of Europe spend the EU's development monies to support some of the richest firms in the world. We conclude that using EU funds as investment incentives to foreign enterprises is wasteful and may reinforce the negative developmental consequences of the dependent market economies.
\end{abstract}

26 Institute for History, Leiden University. Correspondence: v.scepanovic@hum.leidenuniv.nl 27 Centre for Social Sciences, Hungarian Academy of Sciences, Corvinus University of Budapest, Hungary. Correspondence: medve-balint.gergo@tk.mta.hu

Ә Open Access. (C) 2020 Ida Musiatkowska, Piotr Idczak, Oto Potluka and chapters' contributors. Published by De Gruyter. (c) BY-NC-ND This work is licensed under the Creative Commons Attribution-NonCommercial-NoDerivs 3.0 License. https://doi.org/10.1515/9788395720451-006 


\subsection{Introduction}

The debate over East-Central Europe's (ECE) “dependent development” is in full swing. That most of the region's export and much of its output rely on foreign ownedfirms has been well known for over a decade, but has only recently become a matter of heated controversy. This is somewhat surprising given that, until well into the 2000s, foreign direct investment (FDI) had been considered the silver bullet for all of the region's development problems. FDI was supposed to be the cheapest source of capital and know-how, and the fastest way to raise a country's productivity and attain export competitiveness. Across the region, governments of all stripes competed fiercely for external capital, courting foreign firms with attractive incentive packages, "competitive" taxes and "most flexible labour codes in Europe" (Drahokoupil 2008; Šćepanović 2013; 2015). In the years before the 2004 enlargement, the EU itself actively promoted this approach to development (Medve-Bálint 2014).

This is not to say that the downsides have been completely invisible. Academic literature is rife with warnings about the heavy reliance on FDI, potentially leading to limited upgrading prospects, the lack of spill-overs to domestic firms, the persistent wage gap with Western Europe, and the mounting fiscal burden of the region's “dependent market economies" (Nölke \& Vliegenthart, 2009; Bohle \& Greskovits, 2012; Pavlínek \& Žižalová, 2016). Yet, it was not until the aftermath of the global financial crisis that these concerns took political centre stage. Right-wing governments have led the way, complaining about "colonization” by Western European firms, but even more moderate politicians have voiced dissatisfaction with the multinationals' reluctance to share their profits more widely and reduce the wage gap between the new and old EU member states (Bloomberg, 2017; Morawiecki, 2017).

The debate over the economic consequences of EU integration bloomed again in early 2018, in response to a blog post published by the French star economist, Thomas Piketty. In it, he compares profit outflows from East-Central Europe to inflows from EU funds, and concludes that the ECE governments may be right to challenge the narrative of benevolent integration, as the balance of these two external sources of finance actually show that ECE economies have transferred more value to Western Europe than they received (Piketty, 2018). This is certainly an oversimplification-the comparison leaves out all other benefits that have accrued to the region from foreign investment, and offers little justification for the conceptual leap that compares public transfers to private profits (see e.g. Darvas 2018). Even so, Piketty’s numbers do raise some important questions about the relationship between FDI and EU fundsquestions that allow us to depart from the political dispute and reengage in an honest and constructive debate on the benefits and costs of economic integration for EastCentral Europe.

In theory, FDI and EU funds have very little in common. FDI consists of private capital inflows driven by business decisions that follow market advantage and go wherever they perceive a profit opportunity. The EU funds, meanwhile, are public 
transfers from the EU's cohesion policy intended to benefit the least developed member states by generating projects in areas neglected by private investors. Yet, in practice they are linked through the EU's investment incentive framework, which, as we demonstrate in this study, allows the EU funds in ECE to be granted to the multinationals. In this way, the funds intended for developing the poorest areas of the EU are instead used to augment the returns on FDI. This practice is problematic for a variety of reasons. First, there is no evidence that these subsidies are necessary to secure investments. Incentives are usually justified as a way to compensate investors for the perceived disadvantages of a location. Yet, several studies have shown that they are rarely effective when real competitive disadvantages are at play (Blomström \& Kokko, 2003; Oman, 2000). In fact, the value of incentives balloons precisely when the competition for investment takes place between most similar locations-in other words, where the relative disadvantages are the smallest, and the incentives least necessary (Klemm \& Van Parys, 2012; Morisset \& Pirnia, 2000; Thomas, 2011), which is exactly the case across ECE. The incentives are thus not an expression of economic necessity, but of the bargaining power of the multinationals: in other words, rents (Bohle, 2009; Medve-Bálint, 2015). Second, far from being simply wasteful, such subsidies also represent a significant fiscal and opportunity-cost to the host countries, absorbing resources that could be more effectively used elsewhere.

This is all the more obvious in the case of the EU funds, whose purpose would precisely be to compensate for lack of private investment either in less developed regions or in activities such as research, innovation, and environment protection. However, if they simply amplify the profitability of those investments that would have taken place anyway, instead of driving investors to areas and activities where they would not otherwise go, then the EU funds will, contrary to their original purpose, contribute to rising territorial disparities and inequality between foreign and domestic firms. This effect is exactly the opposite of what EU policy makers intended: the poorest countries and regions of the EU may end up paying for investments that would have happened anyway, and instead of levelling the playing field for the weakest players, EU funds are channelled into the pockets of some of the continents' wealthiest firms.

If the use of EU funds as investment incentives is both wasteful and counterproductive, then why does it occur? We argue that the combination of ECE's structural dependence on foreign companies and the regulatory flexibility of the European competition policy allows for this outcome. We demonstrate the mechanism both conceptually and empirically. First, we show how the European regulatory conditions for offering state aid as investment incentives enable ECE-governments to grant subsidies to large multinational firms, and how EU funds may become part of these incentives. Next, by tracing the allocation of EU funds to the automotive industry in two ECE-countries-Poland and Romania-we examine the extent to which EU funds support investments of multinational firms, and whether those grants incentivize innovative or routine investments. In doing so, we also contribute to the larger debate on how EU policies affect development in its peripheries. As 
we argued elsewhere (Medve-Bálint \& Šćepanović 2019), the EU’s competition and cohesion policy are also among the most powerful tools that the dependent market economies have at their disposal to overcome the semi-peripheral position in the European and global economy. Nevertheless, while this transnational industrial policy has the potential to bring considerable developmental benefits, there are also important limitations. In this chapter we focus on these limitations, and highlight ways in which the policy should be adjusted to truly serve its purpose.

While subsidies to FDI in ECE have often been subject to controversy over the years, both in the region itself and in the EU, there has been surprisingly little research into the extent to which EU funds have become part of this incentive system. In this research, we offer an exploratory analysis of this problem, by highlighting how Poland and Romania distribute EU funds to private firms in the automotive sector. We seek to answer the following questions: (1) to what extent are EU funds distributed to foreign firms and (2) to what extent are these funds used to stimulate new investment, as opposed to providing routine subsidies to investments that would have happened even in the absence of incentives?

Our analysis builds on a unique dataset compiled by cross-referencing information on the distribution of EU funds in the 2007-2013 programming period to private companies in Poland and Romania, with information on company characteristics such as size, ownership, and market performance. As this is an exploratory analysis, we limit our dataset to one industry, the automotive, which is a leading sector in both countries, and one in which pressure to provide incentives is large, due to its oligopolistic structure and fierce competition between different production locations (Kolesár, 2006; Thomas, 2011). It is, however, also an industry in which foreign companies are dominant and where domestic firms have been struggling to break in to even the lower tiers of the value chains (Pavlinek \& Janák, 2007; Pavlínek \& Žižalová, 2016; Šćepanović, 2013), which is why one would expect the governments to use the EU funds' in-built preference for small and medium companies to support domestic firms. The two country cases thus also help to see how the balance between the promotion of domestic and foreign firms is struck in different domestic contexts.

The rest of this chapter is organized as follows: Section 1 reviews the EU regulations on the use of EU funds to support private investment in order to gauge theoretically the extent to which these can be used as means to attract FDI. The first part of Section 2 looks into the distribution of EU funds to private companies in Poland and Romania, and evaluates the effect of ownership on the distribution of funding. The quantitative analysis is then complemented in the second part of Section 2 by qualitative information on the projects that received funding. The final section details our conclusions. 


\subsection{The EU's Approach to Subsidies: Market-Preserving, Market- Correcting, or Market-Amplifying?}

We have argued above that the use of public funds to attract mobile multinational firms has significant economic downsides. We should also stress that the EU is well aware of these problems and has, over the years, built a system of regulations to minimize them. The cornerstone of this framework is the EU's state-aid regime, one of the key pillars of the common competition policy. The main purpose of the policy is to preserve the integrity of the single market, by prohibiting any state aid that may distort intra-EU competition by "favouring certain undertakings or the production of certain goods" (Article 107 of the Treaty on the Functioning of the European Union) ${ }^{28}$. The same article, however, relaxes this market-preserving logic by introducing a number of caveats. The aid "may be considered to be compatible with the single market" if it is given to "promote economic development" in backward regions, or those with high unemployment; promote "projects of common European interest"; or "remedy a serious disturbance in the economy of a Member State"29-in other words, in order to correct the market's failure to ensure sufficient investment in certain activities or regions.

The phrasing of Article 107 gives the Commission significant discretion to decide on how to strike the balance between the two principles of state aid. Starting in the late 1980s, the Commission had assumed an activist attitude, interpreting the meaning of "state aid" very broadly (Wishlade, 2015a), and applying it with zeal. Until 1998 for instance, the member states were expected to clear all instances of state aid with DG Competition. This was partly driven by an ideological opposition to industrial policy, and partly by the types of state aid that became most prominent in the wake of the two oil crises and which the Commission considered particularly distortionary: aid to uncompetitive sectors, or rescue and restructuring aid to the "national champions." Since the late 1990s, the idea that the states are responsible for promoting economic growth has returned, at least as it concerns "horizontal" forms of aid, such as those granted in accordance with general criteria, instead of targeting specific sectors or firms. The obligation to notify all individual instances of aid has been replaced by the so-called Block Exemption Regulations (BER) and Regional Aid Guidelines (RAG). These schemes must be vetted and approved in advance by the Commission, and the Commission reserves the right to periodically review their application, but as long as they fall within these schemes, individual cases need no longer be notified ${ }^{30}$.

28 Article 107(1) of the TFEU replaced the substantially identical Article 87 of the EC Treaty.

29 Article 107(3) of the TFEU.

30 Large investment projects receiving aid are still subject to notification. The thresholds, above which an investment is considered large, are set at the regional level (NUTS 3) by the Commission. 
The market-correcting logic of these schemes is reflected in the Commission's efforts to encourage investments that are considered "additive"-i.e. those unlikely to take place without public support: investment by small and medium enterprises (SMEs), in research and innovation, training, and in environmentally-friendly technologies (Blauberger, 2009). By contrast, aid to "traditional” investmentsi.e. investment in buildings and equipment, especially by large firms-has been increasingly subjected to tighter conditions ${ }^{31}$. Finally, to prevent opportunistic behaviour by companies, recipients of state aid must promise to retain operation for at least 5 years or repay the aid; and they may not receive aid for a project if they had recently closed a similar operation in another EU country (European Commission, 2013).

In spite of its soft market-correcting element applied to less developed member states, the EU's state aid regime relies primarily on the market-preserving logic of the competition policy, which seeks to preserve the integrity of the market by discouraging public support to private firms. The EU funds, on the contrary, are predominantly driven by a market-correcting logic, which attempts to prevent growing disparities between countries and regions by compensating for the failure of private funding in reaching backward areas of the EU. This is also why the EU funding for private firms emphatically favours support to small and medium enterprises (SMEs), whichunlike most large firms-have a more difficult time accessing private capital markets. The market-correcting principles and safeguards applied by the EU funds are broadly similar to those stipulated in the state aid regulations. For example, majority of the funds are only available in the least developed areas (those with GDP per capita under $75 \%$ of EU average) and are thus expressly used to promote economic development and address market-induced inequality. However, the funds are also meant to promote horizontal and additive investment objectives through special funding lines dedicated to SMEs, R\&D, innovation, and environment. Most of these funding lines exclude large firms as beneficiaries. To prevent circumvention of this rule by multinationals, capital connections are inspected to determine the size of the firm: its global size (i.e. number of employees/turnover worldwide) is taken into account and not merely its size in the country of application.

All things considered, the market-preserving approach, which ensures that uncompetitive firms and sectors are not artificially propped up by public funds, and the market-correcting approach, which addresses low supply of private investment

31 The 2002 Multi-sectoral framework on regional aid for large investment projects introduced a formula that progressively reduces the applicable aid ceilings for all investments exceeding EUR 50 million (European Commission 2002). The subsequent Guidelines on national regional aid for 20072013 also introduced the requirement that the state must be able to demonstrate "incentive effect" of aid measure (i.e. that aid would not otherwise take place) as well as "proportionality" of aid and the lack of "negative effect” on EU's economy (European Commission, 2006). 
in certain areas and activities, include enough safeguards to successfully contain the negative effects of subsidy competition among the EU member states. Nevertheless, there are still a few reasons why, in the Eastern member states, the EU may not be fully effective at minimizing the misuse of investment incentives, including through its own funds.

First, the state aid regime allows poorer member states and regions to grant higher subsidies to private firms relative to the size of the investment, even when specific features of the location such as labour costs or agglomeration effects would in themselves guarantee profitability ${ }^{32}$. Nearly all regions in ECE fall below the EU deprivation threshold, which means that they are allowed to offer both national state aid and EU funds to prospective investors. Second, large foreign investors have become accustomed to receive incentives, and do not shy away from extracting them by orchestrating "beauty contests" between different shortlisted locations. At the same time, the ECE's structural dependence on FDI has ensured that their governments try to work around the system's limitations in order to offer as much aid as possible. Third, although in principle the Commission favours SMEs and additive investments as targets of EU funds, in practice the process of funding allocation has created pressures on the member states to absorb the EU funds as quickly and efficiently as possible. In absence of adequate domestic institutional structures, contracting the funds to large companies can serve as a solution to the absorption problem because it is easier to manage a small number of big contracts with large foreign firms than to administer a high number of small grants signed with SMEs. This is reflected in the fact that the ECE governments had insisted that traditional investments, including those by large firms, remain eligible for the EU funds. ${ }^{33}$ Fourth, the competitive allocation of EU funds-though it ensures efficiency of spending and increases overall fund "absorption capacity"-also implies that funds are awarded to the already most competitive and best prepared firms. In the context of the ECE dependent market economies, where public policy is already geared towards attracting mobile transnational capital, this means that public subsidies will be allocated according to the market power of the applicant, and diverted from domestic SMEs to foreign multinationals. This effect is likely to arise even without intentional manipulation on the governments' part, as the internal capacities of large firms allow them to submit better fund applications than most of the domestic SMEs. Consequently, with these mechanisms at play, the main market-correcting instrument of EU-integration may-

\footnotetext{
32 In the years prior to the ECE's accession to the EU, the companies were actually asked to calculate the cost difference between investing in the "disadvantaged" areas of EU-15 and investing in the candidate countries in order to obtain support in the former. In all of these cases, the calculations showed a significant cost advantage to investing in the ECE (Šćepanović, 2013).

33 We thank an anonymous Polish state-aid expert for mentioning this aspect (Interview in Warsaw, 30 November 2017).
} 
ironically-reinforce the negative outcomes of the dependent developmental model. In this way, EU funding may become its own parody: a market-amplifying instrument.

To be sure, both the state aid regulations and the EU funds have been instrumental in helping ECEs to manage their dependence on external capital. The legal restrictions on subsidies have allowed them to resist more onerous demands by the multinationals, and enforce some rules over the kinds of projects that may bid for support. The availability of the EU funding has created additional opportunities for these states to reinvent their industrial policies (Medve-Bálint \& Šćepanović, 2019). At the very least, the use of EU funds for investment-promotion purposes may relieve the pressure on the public budgets and alleviate distributional tensions, allowing diversification of support to different types of firms and projects. At best, it may help the Eastern member states nudge the multinational companies towards new investments that contribute to industrial upgrading instead of simply exploiting their low-cost advantage.

Whether or not the EU funds end up being a market-correcting tool, drawing investments to new actors and activities, or a market-amplifying vehicle that only lowers investment costs for the most powerful firms, depends in the end on how they are used. How much of the EU funding actually goes to the multinational firms? Does it mainly support routine investments that would have likely happened anyway, or does it facilitate investments in new directions, such as research and development $(R \& D)$ ? Is the current extent of policy coordination sufficient, or can the EU do more to close the grey areas that permit its poorest regions to spend the most on incentives of dubious value? Surprisingly enough, there is very little empirical research to answer these questions one way or another. Other authors have acknowledged the overlap and the possible contradictions between the EU state-aid and regional-development policies (e.g. Thielemann, 2002; Wishlade, 2008), but the developmental aspects of the relationship between state-aid control and cohesion policy have just begun to attract scholarly interest (Streb, 2013). In the next section, we use data from two Eastern member states, Poland and Romania, to break new empirical ground on this front and investigate to what degree and in which ways the EU funds have been used for investment promotion purposes.

\subsection{EU Funds as a Tool of Investment Promotion: Evidence from Poland and Romania}

To understand how the EU funds are used as a form of subsidy to FDI, in this section we examine the allocation of funding to private firms in the automotive industry in Poland and Romania. The industry has long been one of the primary beneficiaries of public funding, for a number of reasons. The first is its relative size. Automotive production takes place in large industrial agglomerations that bring significant benefits in terms of employment and output. In Poland and Romania, the automotive 
industry broadly understood (including all the primary component providers) accounts for $10 \%$ and $17 \%$ of industrial value added-equivalent to respectively $3 \%$ and 5\% of total private sector GDP ${ }^{34}$. The industry's contribution to export is even more remarkable: $15 \%$ of all commodity exports in Poland and 20\% in Romania are directly related to the automotive sector ${ }^{35}$. Even more importantly, the industry is a centrepiece of a complex production network. With supply chains stretching far into many other industrial branches, it holds the promise of driving forward the entire manufacturing sector (Lee \& Cason, 1994).

The second reason is the industry's concentration. A few global manufacturers control the majority of production worldwide, and thus command enormous bargaining power. Nowhere has this been more evident than in the post-socialist Eastern and Central Europe, where regional governments did everything in their power to attract the automotive giants in order to save their industries after the collapse of socialism. They assumed most of the restructuring costs of the former national champions so that the new owners could take over streamlined, debt-free companies, usually for symbolic amounts (Balcet \& Enrietti, 1998; Dörr \& Kessel, 2002). They offered tax breaks, direct grants, discounted land purchase, dedicated infrastructural investments to connect the factories to the Western transportation network, and, as long as the trade liberalization schedule with the EU permitted it, they also maintained a modicum of import restrictions in order to reward incoming investors with privileged access to the local market (Antalóczy \& Sass, 2001; Cass, 2007; Domański, 2005; Drahokoupil, 2008). Some went so far as to stand up to the EU in defending the concessions granted to the automotive investors. In the run-up to the accession, the Polish state frequently clashed with the Commission over aid to the Korean carmaker Daewoo, the continuing protection of the domestic market in the guise of "environmental" ban on imports of used cars from Western Europe, and generous tax holidays in the Special Economic Zones (Van Aken, 2007). To this day, the sector remains among the "preferred sectors" on the lists of governments' investment promotion agencies. In Romania, the automotive absorbed nearly $60 \%$ of about EUR 620 million spent on investment incentives in the period between 2007$2016^{36}$. In Poland, more than one third of state-aid funds allocated to large firms under regional-aid schemes in the same period went to the automotive industry-around EUR 580 million in total ${ }^{37}$.

34 Authors' calculations based on Eurostat data.

35 Authors' calculations based on COMTRADE.

36 Authors' calculations based on data from the Romanian Ministry of Finance. Includes aid allocated under assistance schemes GD 1680/2008; GD 753/2008; GD 807/2014; GD 332/2014; GD 1165/2007.

37 Authors' calculations based on data reported by the EU state aid register „Transparency system for regional aid for large investment projects". 
All of this makes the automotive industry the test case for the EU's effectiveness in curbing the excessive use of public funds in the competition for investment. Since enlargement, the ECE's incentive schemes has been brought into line with EU regulations, but in view of their past record and the industry's undiminished power, there are good reasons to expect the governments to continue finding ways to grant automotive multinationals the subsidies they had come to expect. There are, however, even better reasons to ensure that as little public money as possible is spent on incentives to multinationals, least of all from the EU funds. First, as noted in the introduction, there is no evidence that subsidies are economically necessary to attract investment to the region, and most investor surveys already rank ECE as the most attractive area in Europe for automotive production (Deloitte, 2016). Second, although the steady flow of investments by the lead automotive firms has indeed boosted the manufacturing capabilities of the ECE states, it has done so mostly by transplanting the existing supplier networks to these countries, with very little involvement of local companies. With few exceptions, the latter had either been acquired by foreign competitors, or pushed out of the sector altogether, with potentially detrimental consequences for long-term development of industrial capabilities in the region (Pavlínek, 2012; Pavlínek \& Janák, 2007; Šćepanović, 2013). These processes are not peculiar to ECE: product integration and follow-up sourcing have led to growing industry concentration and marginalization of local producers in many parts of the world (Barnes \& Kaplinsky, 2000; Humphrey \& Memedovic, 2003). Yet, in the ECE, their marginalization has been further exacerbated by the fact that most public efforts at industry target foreign companies that already have better access to both capital and technology.

In this section, we examine whether the EU funds are used to broaden the FDIpromotion arsenal or, on the contrary, create opportunities for other firms to join the industry and improve their chances in market competition. To do so, we compiled a dataset that combines information on the distribution of EU funds under the 2007-2013 financing framework, with information on company characteristics, including ownership, size, and performance. The dataset includes information from governments' websites on EU funds, commercial databases EMIS and D\&B, and automotive industry organisations in the two countries. As the automotive supplier base reaches into many different industries, in order to include all the relevant firms, we used information on companies' primary activities as reported in the EMIS database and cross-checked it with the databases maintained by the industry associations (PIM and Automotivesuppliers.pl in Poland, and ACAROM in Romania). This gave us a list of 871 firms in Poland, and 523 in Romania, active in the automotive sector, with complete market and financial profiles. To this, we added information on ownership from D\&B database, and classified as "foreign" those firms whose ultimate owner was registered in another country. As the vast majority of foreign-owned firms in our dataset are large companies with more than 1000 employees globally, we use "foreign" and "multinational" interchangeably in the paper. Finally, we matched the resulting dataset with that containing information on the EU funds in order to identify firms that received support. 
We then performed both quantitative and qualitative analyses on the dataset, complementing it with information from company records, media, and government websites, to answer the following questions: Which characteristics make companies most likely to benefit from the EU funds? And what kinds of projects are most likely to be funded? The following two sub-sections tackle each of these questions in detail.

\subsubsection{EU Funds for the Automotive Industry: Who benefits?}

Table 1 summarizes the key characteristics and structure of automotive industries in Poland and Romania based on the information contained in our dataset. As expected, while the majority of firms in both countries are domestically owned, foreign enterprises overwhelmingly dominate the sector. They are responsible for more than $80 \%$ of employment, $85 \%$ of revenues in the Polish automotive industry, and $89 \%$ of employment and 94\% of revenues in Romania. Their share of EU funding is, however, smaller than their weight in the industry employment and output, though the amount of funding allocated to them is still sizeable: roughly half in Romania and as much as three quarters in Poland.

Table 1: Weight of foreign-owned firms in industry size and funding allocation.

\begin{tabular}{llllll}
\hline & $\begin{array}{l}\text { Number of } \\
\text { firms }\end{array}$ & $\begin{array}{l}\text { Employment } \\
\text { (000s) }\end{array}$ & $\begin{array}{l}\text { Operating } \\
\text { revenue } \\
\text { (EUR mn) }\end{array}$ & $\begin{array}{l}\text { No. firms } \\
\text { receiving } \\
\text { EU funding }\end{array}$ & $\begin{array}{l}\text { Total EU } \\
\text { funding (EUR } \\
\text { mn) }\end{array}$ \\
\hline $\begin{array}{l}\text { Poland } \\
\text { of which \% foreign- } \\
\text { owned }\end{array}$ & 40.6 & 257.2 & 46158.3 & 198 & 298.3 \\
$\begin{array}{l}\text { Romania } \\
\text { of which \% foreign- } \\
\text { owned }\end{array}$ & 523 & 80.7 & 85.1 & 29.9 & 76 \\
\hline
\end{tabular}

Source: Authors' calculations based on the automotive dataset, drawing on EMIS, DB, and government databases on EU funding allocation. Data on revenues and employment refer to year 2016.

The absolute figures also suggest that compared to the national state-aid allocations, the automotive industry does not feature prominently among the beneficiaries of EU funds. In the 2007-13 programming period, the total budget of EU funds amounted to EUR 67.3 billion and 19.7 billion in Poland and Romania, respectively (EC, 2007). By the end of the accounting period (end of 2015), Poland had contracted 95\% of its budget while Romania managed to call in only $71 \%$. According to the official records 
published by the monitoring agencies, of the total national budget, EUR 19.3 billion was distributed to private firms in Poland, compared to just 2.9 billion in Romania. Of this, EUR 298 million (1.5\% of private sector funding) in Poland and EUR 144.5 million $(5 \%)$ in Romania was allocated to automotive firms.

This would suggest that the EU is indeed successful at restricting access of large multinationals to EU funds, privileging a different population of firms. To confirm this, we first ran a logistic regression model and then built a two-step model (Heckman, 1979) to estimate the effects of firm characteristics such as ownership, size, productivity, and firm age, on the probability of receiving funding. In the first step, we performed a logistic regression, estimating the likelihood of obtaining funds, while the second one extends the regression by estimating the size of individual grants (measured as total EU-funding per employee). Firm size was proxied by the number of employees. Firm productivity was measured as operating revenue per employee; age was derived from the company's year of incorporation (when operation in Poland or Romania began); and ownership was identified by the country of the ultimate owner. To check for possible differences in the behaviour of the two countries, in some estimations we introduced an interaction term between the country dummy and the binary indicator for foreign companies. To avoid biased estimates, due to the cross-country differences in average firm size, productivity and size of funds, we divided the firms' operating revenue per employee, and total funds per employee by the corresponding country means. Finally, because the continuous variables showed a strong positive skew, we applied log transformation in order to normalize their distribution. ${ }^{38}$

We summarized the results of the models in Table 2. Models 1 and 2 are the logistic regressions while models 3 and 4 are the two-step models. ${ }^{39}$ Model 1 reveals that all else being equal, greater firm size and firm productivity increase the likelihood of being funded, while foreign ownership decreases it. The age of the firm does not show any significant relationship with the dependent variable. The country dummy is not significant which suggests that holding everything else constant, there is no difference in the likelihood of a Polish and a Romanian automotive firm gaining access to EU support. Model 2 contains the same explanatory variables but also adds the interaction term to the equation. The interaction between the country dummy and foreign ownership is not significant and the coefficient for the country dummy does not pass the $95 \%$ confidence level either. This is consistent with the results of the previous model.

The first stage of the selection models estimates the likelihood of a firm receiving EU funds with a similar logistic model as applied above, and yields virtually identical results. In the second stage, OLS estimation is performed where the amount of funds

38 For the correlation matrix of the explanatory variables, please consult Table A1 in the Appendix 39 As a robustness check, we ran all the models with an alternative indicator of size (total operating revenue). The results remained identical to those reported in Table 2. 
per employee becomes the dependent variable to reveal the relationship between the size of funds and the explanatory factors. In other words, the models estimate the size of EU grants that a firm gets once it is being funded. The results show that-all else held constant-larger firms contract fewer funds per employee, while an increase in productivity is associated with higher grants per worker. It implies that more efficient, more productive firms are able to secure bigger contracts relative to their size. Furthermore, the significant country dummy suggests that enterprises in Poland obtain on average lower EU funding per employee than firms in Romania. This is consistent with the descriptive statistics (Table 1) and reveals that funds distributed to the automotive sector are more concentrated in Romania than in Poland. Finally, the significant negative interaction term between the country dummy and firm ownership reveals that funding per employee for foreign businesses does not differ between the two countries: while the Romanian domestic firms-on average-receive significantly higher grants per worker than the domestically owned companies in Poland, the difference disappears in the case of the foreign-owned enterprises (Figure 1) if we hold all other variables constant. To put it differently, funds are more concentrated on the domestic firms in Romania, which also implies that funding in the automotive sector is less distributive there than in Poland, but the average grants per employee to foreign businesses is similar in the two countries, all else being equal.

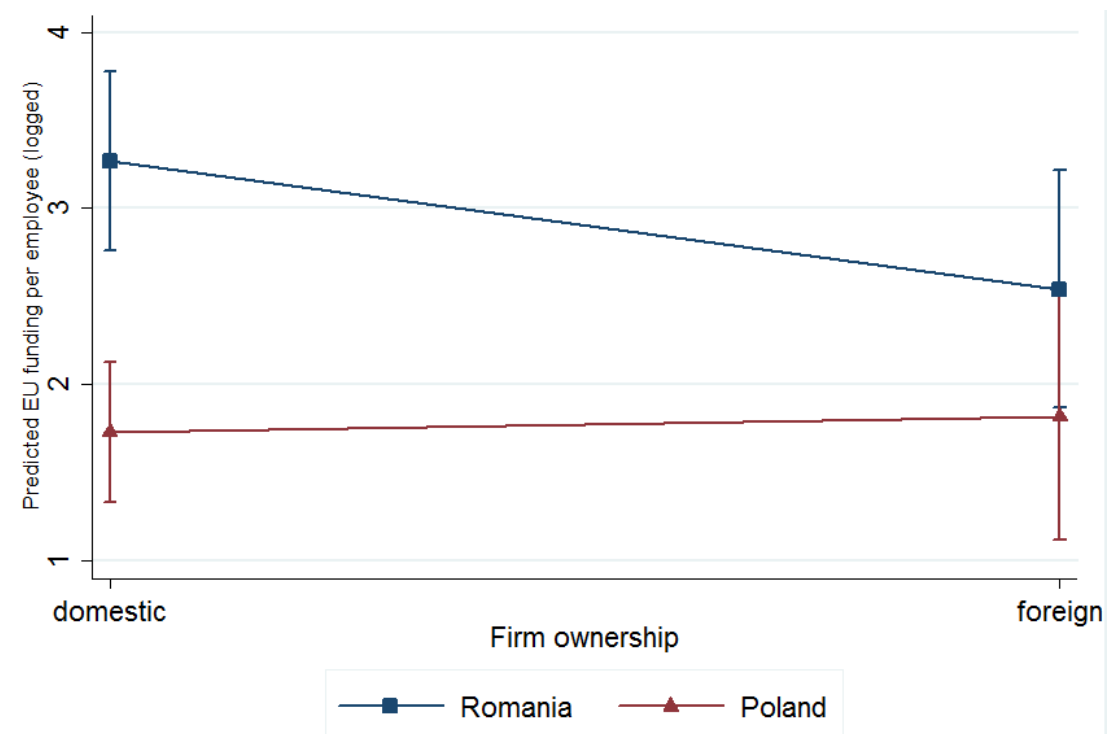

Figure 1: Predicted EU funding per employee with firm ownership by country (Model 4).

Source: Own elaboration. 
The conclusions of our regression models are somewhat conflicting. On the one hand, they show that foreign automotive firms do not enjoy privileged access to EU funding. On the contrary, if two firms are of the same size, age, and productivity, then domestic firms are on average more likely to receive funds. On the other hand, the data reveal a clear preference for larger firms, the vast majority of which are foreign. Even though this trend is somewhat attenuated by the apparent compression of funding amountswith very large firms receiving less per employee than the small firms-there is also evidence that the more competitive (i.e. more productive firms) are also better at obtaining larger grants.

This is in line with the reasoning presented in Section 2, in which we argued that the EU funds may end up being channelled to investment promotion purposes, not because of an explicit bias towards multinationals, but because of the way in which they are distributed. In other words, the problem is not that multinationals are outright privileged-if anything, programme objectives work to prevent their access to the funds-but that they may end up being primary beneficiaries because of the interaction of funding mechanisms and market structure. In an industry in which large multinational firms control the majority of production, so long as they remain eligible for public support and this support is provided on competitive terms, the same characteristics that ensure their market dominance will also conspire to secure them a large proportion of funding. Thus, despite the fact that no preference towards foreign firms can be detected once appropriate controls are introduced, at the macro level, the coincidence of these factors-size, productivity, and ownership-ensure that they receive a very large proportion of EU funds.

The fact that substantial funding goes to multinationals is not yet evidence that programmatic objectives of EU funds to private firms-development of capacities in areas where the private funding is not readily forthcoming-have been overridden by market power. Support to SMEs is one such area; the others are promotion of R\&D activity, investment in human resources, and diffusion of "green" technologies to minimize the environmental impact of industry. In the following section, we examine the extent to which automotive industry projects, which successfully bid for EU funding, fall in line with these objectives.

\subsubsection{What kinds of projects are being financed?}

EU funds are allocated in accordance with the programming documents that must be prepared by each member state ahead of the start of the financing period. The national documents are aligned with the EU's own economic goals, and the national authorities work closely with the European Commission to translate the European objectives into operational programmes (OP) that best suit the country's needs. These typically comprise regional programmes, dedicated to development of specific regions, and sectoral programmes, targeting horizontal objectives such as growth, 
Table 2: Summary statistics of the logistic and the two-step regression models.

\begin{tabular}{|c|c|c|c|c|c|c|c|c|}
\hline & \multicolumn{4}{|c|}{ Logistic models } & \multicolumn{4}{|c|}{ Two-step selection models } \\
\hline & \multicolumn{2}{|l|}{ Model 1} & \multicolumn{2}{|l|}{ Model 2} & \multicolumn{2}{|l|}{ Model 3} & \multicolumn{2}{|l|}{ Model 4} \\
\hline & \multirow[b]{2}{*}{ B } & \multirow[b]{2}{*}{ SE } & \multirow[b]{2}{*}{ B } & \multirow[b]{2}{*}{ SE } & \multicolumn{2}{|c|}{$\begin{array}{l}\text { Second stage: } \\
\text { EU funds/ } \\
\text { employee }\end{array}$} & \multicolumn{2}{|c|}{$\begin{array}{l}\text { Second stage: } E U \\
\text { funds/employee }\end{array}$} \\
\hline & & & & & B & SE & B & SE \\
\hline Constant & .18 & .28 & .02 & .31 & 2.33 & .39 & 2.76 & .42 \\
\hline \multicolumn{9}{|l|}{ Fixed effects } \\
\hline Number of employees & $.52^{\star * *}$ & .05 & $.51^{* * *}$ & .05 & $-.44^{\star * *}$ & .06 & $-.44^{* * *}$ & .06 \\
\hline Op. revenue/employee & $.29^{\star \star \star}$ & .06 & $.29^{\star \star \star}$ & .06 & $.33^{\star \star \star}$ & .10 & $.34^{\star * \star}$ & .11 \\
\hline Age of firm & .00 & .01 & -.01 & .01 & .01 & .02 & .01 & .01 \\
\hline Foreign-owned & $-1.81^{* * *}$ & .21 & $-1.56^{* * \star}$ & .32 & -.17 & .24 & $-.73^{\star * *}$ & .31 \\
\hline Poland & .21 & .15 & $.36^{*}$ & .20 & $-1.16^{\star * \star}$ & .22 & $-1.54^{* \star *}$ & .25 \\
\hline \multicolumn{9}{|l|}{ Interaction effects } \\
\hline Poland * foreign firm & & & -.35 & .33 & & & $.81^{\star *}$ & .41 \\
\hline & & & & & \multicolumn{2}{|c|}{$\begin{array}{l}\text { First stage: } \\
\text { selection of } \\
\text { firms }\end{array}$} & \multicolumn{2}{|c|}{$\begin{array}{l}\text { First stage: } \\
\text { selection of firms }\end{array}$} \\
\hline Constant & & & & & .04 & .11 & .04 & .11 \\
\hline Number of employees & & & & & $.29^{\star * \star}$ & .03 & $.29^{\star \star \star}$ & .03 \\
\hline Op. revenue/employee & & & & & $.16^{* * *}$ & .04 & $.16^{\star * \star}$ & .04 \\
\hline Foreign-owned & & & & & $-.98^{\star * *}$ & .11 & $-.98^{\star * *}$ & .11 \\
\hline Poland & & & & & .12 & .09 & .12 & .09 \\
\hline Mills lambda & & & & & $.21^{*}$ & .13 & $.23^{*}$ & .14 \\
\hline rho & & & & & $.15^{\star}$ & .10 & $.15^{\star}$ & .08 \\
\hline sigma & & & & & $1.50^{\star * \star}$ & .08 & $1.49^{\star \star \star}$ & .08 \\
\hline $\mathrm{N}$ (uncensored) & 1346 & & 1346 & & $1345(2$ & 79) & $1345(2$ & \\
\hline -2Log-likelihood & -1189.1 & & -1187.9 & & -2204.8 & & -2200.9 & \\
\hline Wald Chi-square & $133.1^{* * *}$ & & $136.9^{\star \star *}$ & & $107.8^{\star * *}$ & & $133.95^{\star}$ & \\
\hline Pseudo R-squared & .14 & & .14 & & & & & \\
\hline
\end{tabular}

Unstandardized coefficients, robust standard errors.

${ }^{*} p<.1^{* *} p<.05^{* * *} p<.01$

Source: Own elaboration 
competitiveness, or environment. Each operational programme is then subdivided into Priority Axes (PA), each with their own budget line, and within these into specific measures and areas of interest. Private firms do not have equal access to all OPs, at least not as primary beneficiaries. Most funding under regional OPs (ROP), for instance, go to public authorities for investments in infrastructure, and the financing of private sector activities is strictly limited to SMEs. Under other OPs, access may be limited to firms in certain sectors such as energy, water, or transport.

In the 2007-2013 programming period, the overwhelming portion of EU funding to the automotive industry in Poland came from OP Innovative Economy (86\%) and, to a lesser extent, from the 16 regional OPs and the OP for the development of Eastern Poland (12.2\%) and OP Human Capital (2\%). In Romania, nearly all funding (97\%) came from OP Increase of Economic Competitiveness, followed by OP Human Capital (3\%) (Table 3).

Table 3: Distribution of EU funds to the automotive industry by Operational Programme.

\begin{tabular}{|c|c|c|c|}
\hline Operational Programme & $\begin{array}{l}\text { Total funding to } \\
\text { private firms } \\
(\mathrm{mn} \text { EUR) }\end{array}$ & $\begin{array}{l}\text { Automotive } \\
\text { industryb }^{\mathrm{b}}(\mathrm{mn} \\
\text { EUR) }\end{array}$ & $\begin{array}{l}\text { \% from all } \\
\text { funding to } \\
\text { automotive }\end{array}$ \\
\hline \multicolumn{4}{|l|}{ Poland } \\
\hline OP Regional & 3055.7 & 28.3 & $9.5 \%$ \\
\hline $\mathrm{OP}$ Infrastructure and Environment & 10002.7 & 0 & \\
\hline OP Innovative Economy & 4550.9 & 255.8 & $85.8 \%$ \\
\hline OP Human Capital & 1524.2 & 5.9 & $2 \%$ \\
\hline OP Development of Eastern Poland & 178.1 & 8.2 & $2.7 \%$ \\
\hline Total & 19311.6 & 298.2 & \\
\hline \multicolumn{4}{|l|}{ Romania } \\
\hline OP Regional & 553.8 & 0.6 & $0.4 \%$ \\
\hline Op Environment & 91.2 & 0 & \\
\hline OP Economic competitiveness & 1676 & 139.6 & $96.5 \%$ \\
\hline OP Human capital & 405.7 & 4.4 & 3.1 \\
\hline OP Transport & 157.3 & 0 & \\
\hline Total & 2884 & 144.6 & \\
\hline \multicolumn{4}{|l|}{ a Total funds contracted by end of 2016} \\
\hline$b$ As defined in our database & & & \\
\hline
\end{tabular}


The structure of Poland's OP Innovative Economy and Romania's OP Increase of Economic Competitiveness differ according to the needs of the two countries, but a few similarities stand out. Both programmes emphasise the need to improve the countries' competitiveness by investing in innovation, and both have priority axes dedicated specifically to funding collaborative and individual projects by private enterprises in research, development, and innovation. Both also have funding lines for projects that consist of investment in fixed assets, such as buildings and equipment, as well as intangible assets such as services, intellectual property, and the like. In principle, large firms should not be allowed to bid for grants that support purchase of capital equipment, as these are essential for the firm's core operations and should therefore easily be funded in the private markets. However, both Poland and Romania resolutely fought the Commission's attempts to exclude large firms from these funding opportunities, citing the overall backwardness of the countries' capital stock and the need for extra support to bring the overall technological profile of the industry closer to the European levels (Government of Romania, 2007; Ministry of Regional Development, 2007). In the final compromise, these budget lines remained open to the large firms, but with a number of caveats.

In Romania, funding for capital equipment purchase is tucked under OP IEC Priority Axis 1 - "An innovative and eco-efficient productive system”, but only 20\% of the allocations under it may be distributed to large firms. By contrast, no such restrictions apply to Priority Axis 2 - "Research, Technological Development and Innovation for Competitiveness”, which funds R\&D-related activities (Government of Romania, Ministry of Economy and Finance, 2007). In Poland, about 70\% of all direct support to OP Innovative Economy is similarly earmarked for support to SMEs. Large firms can access funding for capital investments under Priority Axis "Investments in innovative undertakings", measure 4.5 ("Support for investments of high importance to the economy"), under stipulation that priority will be given to investments "connected with start and development of R\&D activities in enterprises" (Ministry of Regional Development, 2009).

In view of all these efforts to direct funding towards smaller firms and non-routine activities, it is quite surprising that over $80 \%$ of all sectoral funding to automotive industry in both countries went to projects involving purchase of capital equipment and services, compared to just $8 \%$ for R\&D-related projects in Poland and as little as 3\% in Romania (Table 4). Even more disappointing is the fact that the majority of such funding was claimed by multinational companies. As noted above, to the extent that the programme documents allow for EU support to companies' purchase of basic operating assets-factory halls, machinery, licences-they should do so only where private financing is unavailable, or prohibitively costly. This is often the case with SMEs, which find it harder to obtain loans at favourable terms, or with local companies operating with especially out-dated equipment and facing very high costs of replacing their capital stock. It is emphatically not the case with the multinationals, which almost by definition operate at the technological edge and have premium access to 
private financing. And yet, these firms were not only more likely to apply for funds in order to finance investment in basic equipment, but were even less likely than other firms to use EU funding for R\&D-related projects or for investment in human capital development (Figure 2).

Table 4: EU funds to the automotive industry by type of project, excluding funding from ROPs.

\begin{tabular}{lllll}
\hline & Poland & & Romania & \\
\hline & EUR $\mathbf{~ m n}$ & \% total & EUR mn & \% total \\
\hline $\begin{array}{l}\text { Purchase of capital equipment and } \\
\text { other assets }\end{array}$ & 210.6 & $\mathbf{8 0 . 5}$ & 115.7 & $\mathbf{8 1}$ \\
R\&D projects & 21 & 8 & 4.3 & 3 \\
Human capital & 5.8 & 2.2 & 4.3 & 3 \\
Other & 24.2 & 9.3 & 18.5 & 13 \\
Total & $\mathbf{2 6 1 . 6}$ & & $\mathbf{1 4 2 . 8}$ & \\
\hline
\end{tabular}

a "Purchase of capital equipment" includes all projects funded under OP 3, PA 1, measure 3.2.1.1. in Romania, and projects funded under $O P 3, P A 4$, measures 4.4 and 4.5 in Poland. "R\&D projects" includes funding accorded under OP 3, PA 2 in Romania and OP3, PA 1 and PA 4 measure 4.1 in Poland. "Human capital" refers to funding allocated under OP 4 - Human Capital, in both countries.

$b$ "Other" includes funding for increasing energy efficiency of buildings, introduction of IT systems, assistance with registration of intellectual property and internationalization (attending international fairs etc.). This includes measures under $O P$ 3, PA 1, 3.2.1.3.; PA 3 and PA 4 in Romania and $O P$ P PA 3, 5, 6, and 8 in Poland.

Source: Own calculations based on the automotive dataset and governments' data on EU funds.

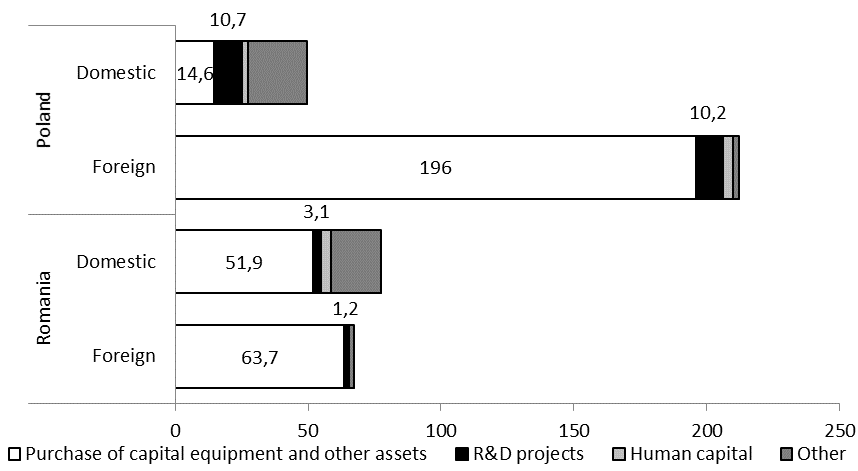

Figure 2. EU funds by type of firm and project, mn EUR.

Note: For detailed description of categories, see Table 4 above.

Source: Own calculations based on the automotive dataset and governments' data on EU funds. 
All of this suggests that a good part of EU funds is being used to fund routine investments of large multinationals. This is not only wasteful, as such activities would have likely happened even in absence of any public support, but also counterproductive, as it diverts funding from firms that would have needed it more and reinforces the competitiveness gap between the large foreign firms and their local counterparts. It is, of course, very difficult to know how innovative a company's project really is. The applications are usually tailored to fit the requirements of the call, and the companies do their best to advertise their own investments as boons to the countries at large. For instance, the EUR 14 million in national and EU funding awarded to Renault in 2014 was widely touted as a subsidy to the development of a competitiveness pole Auto-Muntenia, which would in time contribute to the growth and export competitiveness of the entire regional cluster (Ministerul Economiei, 2014). Yet, all five grants awarded within this package went to two of Renault's subsidiariesAutomobile Dacia and Renault Technologie Roumaine-to construct facilities for the production and testing of a new engine model that had already been announced. The model change came in response to the EU regulation on vehicle emissions requiring all engines installed as of September 2014 to meet Euro 6 standards (Commission Regulation (EU) No. 459/2012), and it is very difficult to imagine that this project would not have happened without the subsidy. Even so, $30 \%$ of the total costs of this EUR 36 million investment had been covered from the EU's coffers.

In Poland, Bridgestone won close to EUR 42 million in 2015 and 2016 to cover about $25 \%$ of the costs of expansion and upgrading of its tyre factories in Poznan and Stargard. The investment was part of a larger EUR 266 million investment package by the Japanese company to expand and upgrade its European facilities. In addition to the two Polish factories, this also included a EUR 70 million investment in Burgos, Spain (Ureta, 2017). Since Burgos has a GDP higher, and unemployment lower than the EU average, it qualifies for minimal EU funds and no state aid, thus the investment went ahead without public support. It is hard to imagine that the Polish investments would have been so much more difficult to finance without public help, especially as the two facilities are decades younger than the one in Burgos. The majority of other investments supported by the EU funds similarly include minor equipment upgrades in anticipation of new product models or expansion of existing facilities. Though the Polish programming documents specifically state that projects related to establishment of R\&D activities will be prioritized, not a single one of the top ten funded projects in the automotive industry mentions establishment or development of an R\&D centre in the project description.

\subsection{Conclusion}

Although the FDI-centred economic strategies of the ECE countries have successfully embedded these economies into the global market, this emerging model of dependent 
development is not without downsides. As domestic economic performance continues to depend on large multinational firms, it is difficult for the public authorities to find ways to steer their business decisions in the direction that would contribute to further domestic development. Meanwhile, keeping the investors happy requires continued provision of various incentives, and thus diverts funds from projects that would assist the upgrading and development of local businesses. In the long run, this may lead to persistent economic disparities between East and West, leaving ECE in a middleincome trap and foreclosing these economies' chances to catch up with the more advanced states.

The European Union's transnational industrial policy provides an important corrective to such practices. Driven by a market-preserving logic, the European stateaid regime, which sees the promotion of private businesses through public funds as a violation of intra-EU competition, sets legal limitations on investment competition. More importantly, the market-correcting EU funds offer compensatory public resources targeting the least developed areas in order to enhance their development by promoting SMEs, research, innovation, and training activities. In this way, the EU funds represent an opportunity to partially mitigate the shortcomings of the dependent development model.

However, in this chapter we have argued that the reach of these policies has been limited. As a consequence of the ECE's structural dependence on FDI, in combination with the peculiarities of EU policies themselves, the EU's marketcorrecting instrument can turn into a market-amplifying one. More specifically, EU funds may be used as incentives to large multinational enterprises, funding routine foreign investment projects that would have been realized even in absence of public grants. This is because EU funds are distributed competitively, and since foreign firms in ECE are eligible to apply, their competitive advantage over most domestic SMEs in preparing quality applications and raising their own resources play to their favour. In addition, contracting large amounts of EU funds to multinationals eases the problems with domestic fund-absorption capacity, which is a particularly pressing issue in the less developed ECE member states. Last but not least, foreign firms are accustomed to receiving sizable subsidies for their investment projects in ECE, a practice that they expect central governments to continue in order to secure further investments. In these circumstances, the distribution of EU funds to the benefit of multinationals seems nearly guaranteed in the Eastern European members.

To test our argument, we analysed the funding contracts to the automotive industry in Poland and Romania in the 2007-2013 programming period. In both countries, the automotive sector plays a key role in the domestic economies and is overwhelmingly dominated by large foreign enterprises. What is more, local businesses in this industry face difficulties with integrating into the value chains controlled by multinational carmakers and their suppliers. Domestic firms in this sector are thus in dire need of gaining access to external capital, such as EU funds, to upgrade their production systems and to survive the fierce market competition. 
However, the structural dominance of foreign enterprises in the automotive industry may divert EU funds from SMEs to the multinational companies.

While our expectations about EU funds being diverted to multinational enterprises have been confirmed, our results reveal a mixed picture. After controlling for several firm characteristics such as size, productivity, and age, we found that foreign automotive firms are in fact less likely to receive EU funds than the domesticallyowned ones. However, both the likelihood of obtaining EU grants and the size of those grants show a strong bias towards larger firms, which in turn, tend to be foreign. This is why a notable share of EU funds contracted to the automotive sector goes to multinationals even though the pattern is considerably more distributive than in the case of traditional state aid disbursed from the national budgets. Firm productivity is also positively associated with EU grants, which confirms the competitive character of fund distribution. While we do not find significant differences between the two countries in the propensity to award EU grants to multinational firms, we do find some differences with respect to funding to domestic firms. Specifically, the distribution of funds is more concentrated in Romania, with fewer SMEs obtaining funds relative to their number in the sector. This is an indicator of the country's lower fund absorption capacity. It also suggests that while the pressure to compete for FDI poses a similar external constraint to ECE governments' space for manoeuvre, the extent to which they are able to take advantage of the tools of the EU's transnational industrial policy also depends on their domestic institutional capacities (see Medve-Bálint \& Šćepanović, 2019).

The problematic nature of the above funding pattern does not necessarily lie in the fact that multinational enterprises obtain EU grants, but that most of those funds support projects that are not innovative in character. As we have shown, the vast majority of EU funds contracted to foreign automotive firms assist the purchase of capital equipment and other assets-or, to put it differently, routine investments that would have been realized without any public support. This contradicts the main objectives of EU funds and may contribute to the negative economic consequences of the dependent development model. While the Commission is aware of the problem, the design of the 2014-20 funding programmes continues to allow it. In the current funding cycle, three PAs of the Smart Growth OP-which, in terms of objectives, has replaced the Innovative Economy OP in Poland-are available to the private sector, and two of them are open to large enterprises. This means that large firms, including multinationals can, in principle, compete for $69 \%$ of the total EU contribution of EUR 7 billion allocated for the three PAs. ${ }^{40}$ The situation is similar in Romania: the

40 The authors' own calculation based on Detailed Description of Priority Axis of Smart Growth Operational Programme 2014-2020, Warsaw: Ministry of Infrastructure and Development, 22 October 2015 (Available: https://www.poir.gov.pl/media/11337/SZOP_POIR_22102015_ang.pdf, accessed on 1 July 2018) 
primary instrument for supporting businesses, the Competitiveness OP, has two PAs and, except for a single action assisting SMEs in accessing venture capital, nearly the entire budget of EUR 1.3 billion is open to large firms as well. ${ }^{41}$ Most notably, the reason that the EU funds may continue to subsidize multinationals is that the same ECE states that are increasingly complaining about being colonized by Western capital, and blaming the EU for it, have not found a way to extricate themselves from structural dependence on FDI and have thus done everything in their power to ensure that the EU funding programmes remain open to large firms.

Our analysis has thus revealed that the structural power of multinationals, and the funding allocation mechanisms combined with the states' dependence on foreign capital, create a perverse outcome: the least developed regions of Europe spend their own, as well as the EU's resources, to finance some of the richest firms in the world. This is not only wasteful, it potentially prevents these countries from overcoming the economic drawbacks of the dependent development model. Nevertheless, the empirical evidence presented here is limited to a single albeit highly important sector, the automotive. Further inquiries should investigate whether or not a similar pattern characterizes the distribution of EU funding contracted to other industries in ECE.

\section{Acknowledgments}

Gergő Medve-Bálint’s research was supported by the MTA Post-Doctorate Research Program of the Hungarian Academy of Sciences (contract no.: PPD-028/2017).

\section{References}

Aken, van, Wim. 2007. 'Mediating Membership: Sectors, States, and Strategies: EU Enlargement Negotiations (1998-2003)'. PhD Dissertation, European University Institute (EUI), Florence.

Antalóczy, Katalin and Magdolna Sass. 2001. 'Greenfield Investments in Hungary: Are They Different from Privatization FDI?’ Transnational Corporations 10(3):39-60.

Balcet, G. and A. Enrietti. 1998. Regionalisation and Globalisation in Europe: The Case of Fiat Auto Poland and Its Suppliers. Quaderni di Ricerca. 1. Torino: Dipartimento di Economia.

Barnes, Justin and Raphael Kaplinsky. 2000. 'Globalization and the Death of the Local Firm? The Automobile Components Sector in South Africa'. Regional Studies 34(9):797-812.

Blauberger, Michael. 2009. 'Compliance with Rules of Negative Integration: European State Aid Control in the New Member States'. Journal of European Public Policy 16(7):1030-46.

Blomström, Magnus and Ari Kokko. 2003. The Economics of Foreign Direct Investment Incentives. Working Paper. 9489. National Bureau of Economic Research.

41 The authors' own calculation based on Programul Operational Competitivitate (Available: http://www.fonduri-structurale.ro/Document_Files/FonduriStructuralesideInvestitii20142020/00017898/7omhh_POC.pdf, accessed on 1 July 2018) 
Bloomberg. 2017. 'Czech Leader Vows More Pressure on Foreign Investors Over Wages'. Bloomberg, April 18.

Bohle, Dorothee. 2009. 'Race to the Bottom? Transnational Companies and Reinforced Competition in the Enlarged European Union’. Pp. 163-86 in Contradictions and Limits of Neoliberal European Governance: from Lisbon to Lisbon, edited by B. van Apeldoorn, J. Drahokoupil, and L. Horn. Basingstoke [England] ; New York: Palgrave-Macmillan.

Bohle, Dorothee and Béla Greskovits. 2012. Capitalist Diversity on Europe's Periphery. Cornell University Press.

Cass, F. 2007. 'Attracting FDI to Transition Countries: The Use of Incentives and Promotion Agencies'. Transnational Corporations 16(2):77-122.

Darvas, Zsolt. 2018. 'What Is the Financial Balance of EU Membership for Central Europe?' Bruegel. Retrieved (http://bruegel.org/2018/02/what-is-the-financial-balance-of-eu-membership-forcentral-europe/).

Deloitte. 2016. 'Central Europe as a Focal Point of the Automotive Industry'.

Domański, Bolesław. 2005. 'Transnational Corporations and the Post-Socialist Economy: Learning the Ropes and Forging New Relationships in Contemporary Poland'. Pp. 147-72 in C. Alvstam, E. Schamp (eds) "Linking Industries Across the World: Processes of Global Networking. Ashgate: Aldershot.

Dörr, Gerlinde and Tanja Kessel. 2002. Cooperation and Asymmetry: The Development Profile of an East-West Corporate Project. FS II 02-201. Wissenschaftszentrum Berlin.

Drahokoupil, Jan. 2008. Globalization and the State in Central and Eastern Europe: The Politics of Foreign Direct Investment. London: Routledge.

European Commission. 2006. 'Guidelines on National Regional Aid for 2007-2013’. Official Journal of European Union 54:13-44.

European Commission. 2013. 'Guidelines on National Regional Aid for 2014-2020.' Official Journal of European Union 209:1-45.

European Commission DG Regio. 2007. Cohesion Policy 2007-2013. National Strategic Reference Frameworks. Luxembourg: Office for Official Publications of the European Communities.

Government of Romania. 2007. 'Sectoral Operational Programme “Increase of Economic Competitiveness"'.

Government of Romania, Ministry of Economy and Finance. 2007. 'Sectoral Operational Programme "Increase of Economic Competitiveness"'.

Humphrey, John and Olga Memedovic. 2003. The Global Automotive Industry Value Chain: What Prospects for Upgrading by Developing Countries. United Nations Industrial Development Organisation.

Klemm, Alexander and Stefan Van Parys. 2012. 'Empirical Evidence on the Effects of Tax Incentives'. International Tax and Public Finance 19(3):393-423.

Kolesár, Peter. 2006. Race to the Bottom? The Role of Investment Incentives in Attracting Strategic Automotive Foreign Direct Investment in Central Europe. MA Dissertation. Budapest: Central European University, Department of International Relations and European Studies.

Lee, Naeyoung and Jeffrey Cason. 1994. 'Automobile Commodity Chains in the NICs: A Comparison of South Korea, Mexico and Brazil'. in Gereffi and Korzeniewicz (eds.) Commodity Chains and Global Capitalism. London: Praeger.

Medve-Bálint, Gergő. 2014. 'The Role of the EU in Shaping FDI Flows to East Central Europe'. JCMS: Journal of Common Market Studies 52(1):35-51.

Medve-Bálint, Gergő. 2015. Converging on Divergence: The Political Economy of Uneven Regional Development in East Central Europe After the Change of Regime (1990-2014). PhD Dissertation. Budapest: Central European University. 
Medve-Bálint, Gergő and Vera Šćepanović. 2019. ‘EU Funds, Domestic State and the Development of Transnational Industrial Policies in Europe's Periphery'. Review of International Political Economy, doi: 10.1080/09692290.2019.1646669.

Ministerul Economiei. 2014. 'Comunicat de Presă'. Retrieved (http://www.minind.ro/presa_2014/ februarie/24_feb_comunicat_Semnare_contracte_Pol_Auto_Muntenia.pdf).

Ministry of Regional Development. 2007. 'Operational Programme Innovative Economy 2007-2013'.

Ministry of Regional Development. 2009. 'Detailed Description of the Priorities of Operational Programme Innovative Economy 2007-2013'.

Morawiecki, Mateusz. 2017. 'Confirmation Speech of the Prime Minister to the Polish Parliament', December 12, Warsaw.

Morisset, Jacques and Neda Pirnia. 2000. How Tax Policy and Incentives Affect Foreign Direct Investment. A Review. Policy Research Working Paper Series. 2509. World Bank and International Finance Corporation Foreign Investment Advisory Service.

Nölke, Andreas and Arjan Vliegenthart. 2009. 'Enlarging the Varieties of Capitalism: The Emergence of Dependent Market Economies in East Central Europe'. World Politics 61(4):670-702.

Oman, Charles. 2000. Policy Competition for Foreign Direct Investment. A Study of Competition among Governments to Attract FDI. Paris: Development Centre of the Organisation for Economic Cooperation and Development (OECD).

Pavlínek, Petr. 2012. 'The Internationalization of Corporate R\&D and the Automotive Industry R\&D of East-Central Europe'. Economic Geography 88(3):279-310.

Pavlínek, Petr and L. Janák. 2007. 'Regional Restructuring of the Skoda Auto Supplier Network in the Czech Republic'. European Urban and Regional Studies 14(2):133-55.

Pavlínek, Petr and Pavla Žížalová. 2016. 'Linkages and Spillovers in Global Production Networks: Firm-Level Analysis of the Czech Automotive Industry'. Journal of Economic Geography 16(2):331-63.

Piketty, Thomas. 2018. '2018, the Year of Europe'. Le Monde. Retrieved (http://piketty.blog.lemonde. $\mathrm{fr} / 2018 / 01 / 16 / 2018$-the-year-of-europe/).

Šćepanović, Vera. 2013. FDI as a Solution to the Challenges of Late Development: Catch-up without Convergence? PhD Dissertation. Budapest: Central European University.

Šćepanović, Vera. 2015. 'Have Your Competitiveness and Eat It Too. The Pull and Limits of Cost Competition in Hungary and Slovakia'. Pp. 190-209 in Market expansion and social dumping in Europe. London: Routledge.

Streb, Hagen. 2013. 'State Aid Policy, Territoriality and Federalism: EU Scrutiny and Control of Regional Aid and the Supranationalisation of Subnational Autonomy in Federal Member States'. Journal of Industry, Competition and Trade 13(1):129-41.

Thielemann, E. 2002. 'The Price of Europeanization: Why European Regional Policy Initiatives Are a Mixed Blessing'. Regional \& Federal Studies 12(1):43-65.

Thomas, Kenneth P. 2011. Investment Incentives and the Global Competition for Capital. Basingstoke: Palgrave Macmillan.

Ureta, R. T. 2017. ‘Bridgestone Se Reorientará Hacia El Neumático Premium'. El Correo de Burgos, October 20.

Wishlade, Fiona. 2015. Another Generation in Competition Policy Control of Regional Development Policy. EORPA Paper 14/5.14/5. Glasgow: European Regional Policy Research Consortium, University of Strathclyde.

Wishlade, Fiona G. 2008. 'Competition and Cohesion - Coherence or Conflict? European Union Regional State Aid Reform Post-2006'. Regional Studies 42(5):753-65. 


\section{Appendix}

Table A1: Correlation matrix of the explanatory variables.

\begin{tabular}{|c|c|c|c|c|c|}
\hline & $\begin{array}{l}\text { Operating } \\
\text { revenue }\end{array}$ & $\begin{array}{l}\text { Number of } \\
\text { employees }\end{array}$ & $\begin{array}{l}\text { Operating } \\
\text { revenue per } \\
\text { employee }\end{array}$ & Age & Foreign-owned \\
\hline Operating revenue & 1 & & & & \\
\hline $\begin{array}{l}\text { Number of } \\
\text { employees }\end{array}$ & $.83^{* * *}$ & 1 & & & \\
\hline $\begin{array}{l}\text { Operating revenue } \\
\text { per employee }\end{array}$ & $.62^{* * *}$ & $.08^{\star \star \star}$ & 1 & & \\
\hline Age & $-.09^{* \star *}$ & $-.17^{\star \star \star}$ & -.04 & 1 & \\
\hline Foreign-owned & $.54^{* * *}$ & $.46^{* * *}$ & $.33^{\star \star \star}$ & $-.05^{* *}$ & 1 \\
\hline
\end{tabular}

${ }^{* *} p<.05{ }^{* * *} p<.01$

Source: Own elaboration

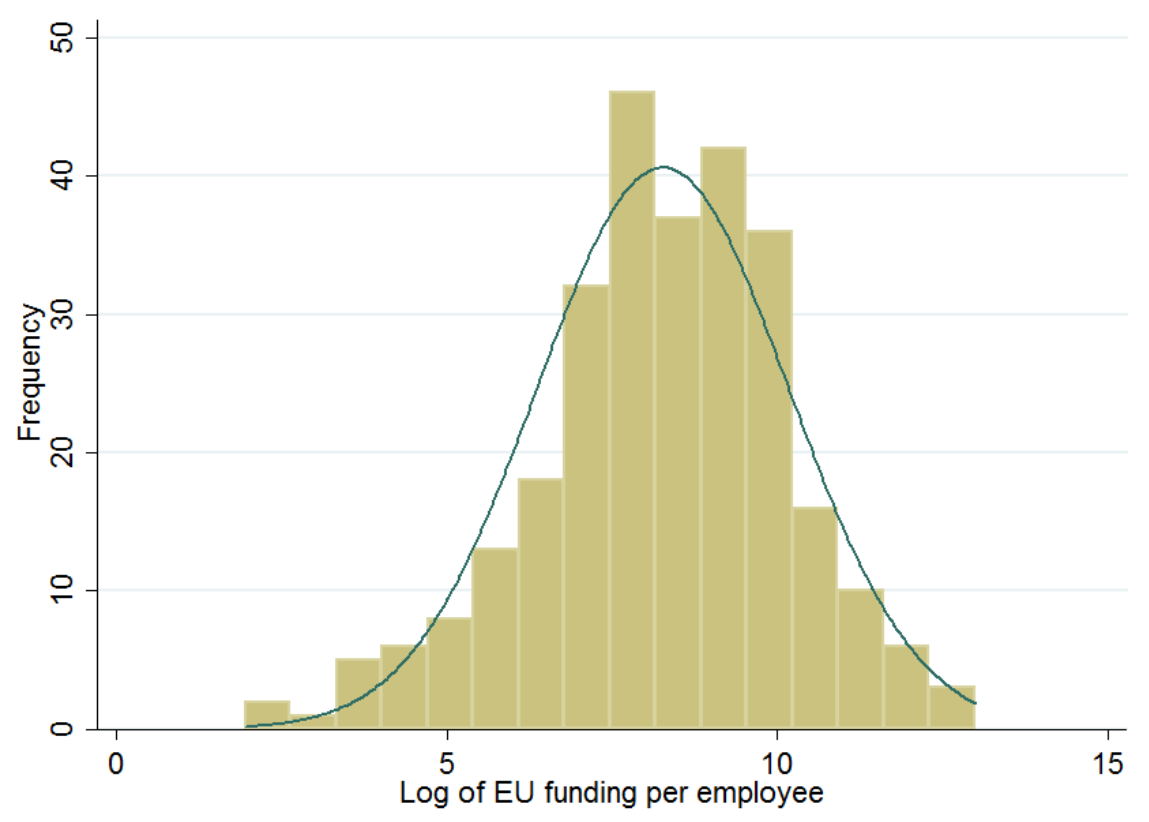

Figure A1: Distribution of EU funding per employee (logged), non-zero cases.

Source: Own elaboration 
Table A2: Descriptive statistics of the independent variables. (Original scales)

\begin{tabular}{|c|c|c|c|c|}
\hline Name of variable & Min. & Max. & Mean & SD \\
\hline EU funds per employee (EUR) & 0 & 438467 & 3519.6 & 20885.7 \\
\hline $\begin{array}{l}\text { Total operating revenue } \\
\text { (mn EUR) }\end{array}$ & 0 & 4623.9 & 49.38 & 207.80 \\
\hline Number of employees & 1 & 13835 & 350.23 & 935.14 \\
\hline $\begin{array}{l}\text { Operating revenue per employee } \\
\text { (mn EUR) }\end{array}$ & 0 & 10.9 & .192 & .62 \\
\hline Age of firm & 1 & 58 & 13.58 & 6.36 \\
\hline
\end{tabular}

Source: Own elaboration 